\title{
Learning through Serving: Service Learning as an Alternative Practicum Platform for Pre-service EFL Teachers
}

\author{
Roza Kazakbaeva \\ Kyrgyz State University
}

\begin{abstract}
This paper presented the findings of the study done at English teacher training program at Kyrgyz State University to examine the effectiveness of Service-learning in pre-service teacher education. At the time of Soviet power, its teachers had various outlets for professional development where they learned new methodologies and motivational techniques to teach foreign languages; however, with the demise of the Soviet Union, teachers have few or no outlets for professional development. Therefore, the purpose of the study was to examine the efficacy of the service-learning project when used as an alternative practicum platform to provide EFL preservice teachers with the opportunities to gain hands-on experience in their future professions as well as develop their English language proficiency and civic engagement. The analysis of reflective narratives, classroom observations and focus group sessions revealed that the service-learning project had a positive influence on 1) provided preservice teachers with an authentic experience in teaching academic content; b) connecting second/ foreign language theory to real-life contexts; 3) improve their English language competency; and 4) enhanced their civic engagement. The implications of the study may have potential benefits for teacher education institutions to consider service learning programs as an alternative strategy to provide preservice teachers with a hands-on teaching experience.
\end{abstract}

\section{Introduction}

In Kyrgyzstan, a small, Central Asian republic which was a former Soviet state for more than 70 years, the educational system is experiencing dramatic changes due to social and political changes since the disintegration of the Soviet Union. Specifically, the country is undergoing a rapid increase of enrollment in English programs in both state-run and private universities. At the same time, because of low salaries, scant and costly supplies and inconsistent salary payments, teaching in Kyrgyzstan has become a less desirable occupation [12]. In the late 1990s and early 2000s, governmental attempts have been made to incentivize teaching and update curriculum inherited from the Soviets, but these attempts have failed due to funding, poor managerial and strategic planning capacities and a lack of inadequate teacher training programs [12]. For some, however, learning English remains an attractive gateway to international opportunities - including the lucrative and growing tourism industry. One way to pursue such interests is to teach English. But, despite attractions to teaching English, it is taught employing traditional methods such as grammar translation method and "drill or kill" method [15] which does not adequately meet social and economic needs for learning English. Grammar translation which prevailed in EFL teaching and learning in Kyrgyzstan and other post-soviet countries did not require an appropriate English language proficiency on the part of English teacher which may be attributed to reliance on students' native languages, Russian or Kyrgyz, in explaining grammatical structures or new words. The latter method, "drill and kill", focuses on memorization of discrete chunks of knowledge without understanding; thus, does not promote retention and application of knowledge acquired in the classroom in an authentic context. It is important to highlight that these methods have perfectly served the purpose for EFL teaching and learning behind the "iron curtain" which was the translation of technical and scientific texts for the Soviet Union's industrialization projects [5, p.71]. This suggests that the methods used by EFL teacher during the Soviets fit well the objectives of EFL teaching and learning due to social and political contexts existed during the Soviets. The demise of the Soviet Union has created new social, economic and political context which affected all spheres of life including EFL learning. Starting from the late 1990s all former Soviet Union countries started establishing a wide range of socioeconomic, cultural and political ties other countries which led to the unprecedented popularity of English as an international language of business and communication. This, in turn, required to set up new objectives for the English language learning to meet the growing demands for learning English for business and personal communication. Since the 1990s teaching English and foreign languages, in general, has undergone several changing in terms of objectives and content; however, despite the change of English language learning objectives, the abovementioned methods are at the core in EFL teaching which may be partially due to an inadequate teacher training. One of the examples of a lack of insufficient teacher training can be observed in teachers' use of textbooks, both local and commercial, approved by the Ministry of Education. 
Most teachers experienced and novice teachers, use textbooks as a recipe without evaluating the compatibility of the textbooks' assigned "level" in the commercial textbooks with the real level of their students and relevance of the content to students' context. As for local textbooks published in early 2000 , even though some of the themes are relevant and meaningful to students' context; however, the authors used soviet textbooks template while structuring the textbooks which is mostly discrete teaching each language skill. All these challenges in EFL teaching in Kyrgyzstan can be attributed to the lack of inadequate teacher training programs in the educational system. In this paper, the author will analyze the effectiveness of a service learning project when used as an alternative practicum platform to provide EFL pre-service teachers with the opportunities to learn constructive approaches including but not limited to course design, use of a variety of instructional approaches and materials, classroom observation, assessment tools etc.

\section{Service learning defined}

Service learning can be defined as a union of service and learning which has originated from John Dewey's theory of experience and education which places reflective experience at the center of education [4]. Even though while formulating his theory on education and experience, Dewey did not envision service learning but the fundamental philosophy of his theory "learning from experience" is widely used as a conceptual framework in service learning. Service learning due to its experiential nature has been prevalent in pre-service teacher training programs with the aim to provide pre-service teachers with the opportunity to have practicum before they embark to their teaching career in various educational context for the past several decades. While service learning may seem like a cultural neutral activity, the concept differs from one culture to another. U.S. contexts may include traditions of volunteerism and social activism based in historical events, such as women's suffrage or the Peace Corps [10].

At the time of Soviet power, there was a concept known as obshestvenaya rabota (social work), which encouraged citizens to give back to society. In Kyrgyzstan and many other former Soviet republics, community service (obshestvenaya rabota) was originally voluntary initiative that eventually became "voluntarilymandatory" practice required as a part of all citizen's duties, including teachers which they had to perform this required, yet "voluntary" service. Another social engagement, which is worth to highlight, was so called Timurite movement which was an altruistic youth volunteering. The participants of this movement clandestinely did good deeds: helped the families of the Red Army soldiers and their families cleaning preparing firewood, shoveling snow, combating local gangs etc. As it is obvious that the scope of the abovementioned community services was limited to cleaning, helping farmers and former soldiers or watching neighborhoods. After Soviet rule waned, this type of service disappeared as it often happens when in the attempt to destroy the old regime and establishing the new system of ruling, governments get rid of everything that is associated with the old regime; even though some of the practices are worth keeping and continuing. Therefore, the purpose of this article to introduce a revival of the obshestvenaya rabota spirit, but with a new interpretation which involved a true voluntary service in an educational context. Moreover, the author also realized that in an English language program, this type of service learning could be combined with practical teaching experience to motivate pre-service teachers to learn English and gain hands-on experience in their prospective careers while helping their communities. Finally, while there exists an abundance of motivational approaches in English as a Foreign Language [EFL]teaching, many traditional strategies fail to sustain student interest; therefore, nowadays practitioners and researchers seek non-traditional strategies, and, among them, service learning [8].

\section{Literature review}

Since the introduction of service learning in Northern American universities, many universities now include service learning as a mandatory part of their curriculum. In 1985, the concept was established by several college presidents into a nonprofit association, and by, 2003, about 25 percent of all American colleges became members of Campus Compact [2]. But colleges and universities still struggle with how service learning can provide meaningful help to the community and maintain student accountability [2]. Today it is imperative in our increasingly globalized world to integrate crosscultural values, including volunteerism, in EFL teaching. In many Western universities, this integration has been realized; however, in Russia (and to a larger extent, the countries of Central Asia), maintained that cultural perceptions of volunteerism might cloud understanding and prevent students from engaging in service learning [10]. Specifically, those who remember "volunteering" as schoolchildren might consider the idea of service learning repugnant. Other Sovietinfluenced societies may perceive service learning as charity emanating from superiority, or as distrustful since it comes from strangers [10]. Still, the current literature shows, in some non-Western countries, service learning gaining popularity as a strategy to strengthen and enrich the traditional curriculum in EFL teaching and learning [14], [1], [11], [17]. For example, research 
conducted in Sultanate of Oman, has revealed that service learning was an effective and valued method in EFL teaching. It also had a great impact on student involvement in societal engagement [1]. Another study done by Sun and Fang who employed Service learning in EFL classroom found that the project enhanced EFL students' public speaking-related skills (e.g., idea and content development, and pronunciation), built their confidence in speaking English, and allowed them to develop their own learning process and strategies [13].

\section{Research Design}

The study employed a qualitative methodology to explore the efficacy of the service learning project when used as an alternative practicum platform to provide EFL pre-service teachers with the opportunities to apply classroom knowledge in a practicum as well improve their language proficiency and civic engagement. A service learning project was conducted over one semester (16 weeks) launched at Kyrgyz National University. The service-learning project was offered for the preservice English teachers to help students gain handson experience in their future career as well as develop their language proficiency and social responsibility. The project curriculum was designed and led by pre-service teachers under the researcher's supervision.

\section{Research context}

Kyrgyz National University, the oldest higher education institution in the republic, founded in 1925 as the Kyrgyz Institute of Education. The University has a long history of being a leading educational institution offering quality educational programs in the country. Originally it was founded as the Kirghiz Central Pedagogical College to solve the problems in the training of pedagogical personnel on the territory of the Republic. The first faculty members were invited from other republics of the USSR, mainly from Russia, to ensure the quality of education. In 1932, by the decision of the Council of People's Commissars of the USSR, it was transformed into the Kirghiz Pedagogical Institute. There were only four departments: physics and mathematics, biology, literature and social sciences. Starting from 195,1 it was the Kyrgyz State University offering 56 undergraduate programs, 32 master's programs, and 14 vocational programs. The service-learning project was launched the Methodology Departments at the university's Foreign Languages Department. The curriculum of the projects was implemented in two sites: a center for students from local income families and orphans of the university and parentrun rehabilitation center for children and young adults in a capital city. To solicit on-campus students who were identified to be disadvantaged in some way, the researcher- coordinator communicated eight different departments at Kyrgyz National University. To solicit off-campus students, the researchercoordinator contacted a local parent's association for physically challenged children.

\subsection{Participants}

The participants of the study were twenty-two pre-service EFL teachers enrolled in the English teacher training program of Kyrgyz National University. The participants ranged in age from 17 to 23 years old, 17 female and 5 male students. The researcher recruited participants (pre-service teachers and third- and fourth-year university students) through an open-call advertisement in a Foreign Language Department. About 50 students attended an informational meeting; however, by the end, twenty-two students remained committed to the project completion.

\subsection{Project design}

Prior to implementing the service-learning project, the researcher-coordinator administered focus group to elicit information about their previous knowledge of service learning or other community services. Students' response revealed that students did not understand the concept of service learning. Instead, students confused the volunteerism with obshestvenaya rabota. Therefore, the researcher gave an introductory presentation followed by the discussion about service learning as well as its purpose and implementation to mark the boundaries between service learning and other community services. Since the principle of service learning is volunteerism and community involvement, the researcher asked students who were willing to commit to a consistent schedule through signing an informed consent form to participate in the program. The researcher- coordinator also reinforced that the project was wholly voluntary. After an initial meeting, both researcher and pre-service teachers agreed on the days and venue for the service-learning project. The researcher- coordinator and study participants met twice a week: one meeting for four hours and the second meeting for two hours. The first hour of the first meeting was dedicated for the researcher- coordinator to assist pre-service teachers to develop lesson plans, activity construction, and content development. Here it is important to point out that researcher- coordinator requested pre-service teachers to develop a lesson plan for the first meeting to diagnose/test their skills in this area. The analysis of the lesson plans demonstrated that their previous experience in English language teaching and learning permeated in their lesson plans. They replicated what they have observed as students in the classroom 
which was mostly teacher-centered and whole class oriented leaving no room for pair and group work. In other words, pre-service teachers' approach in lesson designing and delivering was a byproduct of their previous observation and experience in English language teaching and learning. Therefore, the researcher coordinator assisted them to develop lesson plans that were student-centered activities which helped them to move away from traditional language teaching approaches. The second hour the pre-service teachers "rehearsed" the lessons to their project participants. The lesson "rehearsal" part of the project was to test the lesson first, and if needed make some adjustments before delivering. Also, the participants being on their last year study at the teacher training $g$ program did not have the experience to teach in real classrooms; therefore, at the beginning of the program, pre-service teachers were required to teach the lesson for their classmates to gain experience as well as confidence. Eventually, "rehearsing" lessons prior classroom teaching faded out after students developed confidence in their teaching. After each weekly planning session, the pre-service teachers taught English to both oncampus students and off campus, who were divided into four levels based on the results of a written, English diagnostic test. While pre-service teachers delivered the lesson, researcher- advisors observed the lesson and provided feedback on pre-service teachers' lessons.

\subsection{Data collection}

To ensure credibility and validity, the data was collected through observations, reflective narratives, and post-questionnaire. To gather information about the project and its effect on preservice teachers, if any, the researcher began by first observing the preservice teachers. At the end of the project, the researcher conducted reflective narratives in which the researchers sought to understand the pre-service teachers' experience through a special type of conversational interaction on their teaching experiences including but not limited to lesson delivery, classroom management, lesson content and further improvement. All the narratives were transcribed verbatim.

\section{Findings and Results}

The researcher interpreted the data through the lens of the main guiding question: How did service learning promote pre-service teachers' professional and personal growth? The analysis of interviews and questionnaires revealed that, overall, service learning enhanced pre-service teachers' comprehension of the course content while applying the classroom knowledge in an authentic English language teaching context. They admitted that before teaching to students they had to master

the content themselves as well as think which activities would promote to comprehend the content as well as evoke students' interest in performing the tasks. For example, as one of the participants narrated:

Before I ever thought about the connection between lesson objective and lesson activities ... now while developing lesson plans, I think a lot which activity to choose that would engage students in doing the tasks mmm ... I tried to choose creative activities and students liked them.

This and other narratives suggest that participating in SL, pre-service teachers reflect on their teaching by posing questions: Why am doing this? What can be done? What worked and what did not? etc., to ensure engaging and positive learning outcomes. The analysis of the reflective narratives revealed that one of the challenged that most participants faced was classroom management stemming from external and internal factors such as disruptive behavior, an inability of establishing and reinforcing classroom rules, lesson timing, students varied language proficiencies etc. It is interesting to point out that one such challenge in classroom management was due to their students' social backgrounds. For example, participant E narrated:

I wanted to punish some of the students who did not behave well but I know they are orphans ... $\mathrm{mmm}$ ... I did not want to hurt their feelings.

This shows that pre-service teachers were aware of their professional roles in the classroom such facilitators of academic content and skill acquisition by creating a caring environment. However, it seems that pre-service teachers challenged to set boundaries between their nonacademic and academic roles in their teaching. This hindered them from managing classroom which impacted their instruction in general. From this, it is obvious that teacher training programs should include training on how to draw lines between pastoral care and academics, and how much of pastoral care, which is inherently attached to the teaching profession, should be provided to enhance academic knowledge. In other words, preservice teachers should be provided with guideline how their intertwined academic and pastoral roles could positively affect students' academic improvements as well as their personal growth. Also, all participants admitted that they have noticed a significant improvement in their language skills. This they attribute this to the fact that while planning the lessons they read texts, listened to audio materials, formulated questions around the content, looked for definitions of news words etc. While 
delivering lessons they listened to what students produced, asked questions, explained new words and guided discussion which contributed to the improvement their language skills. For example, the excerpt taken from the participant narrative echoes other participants perspectives as well:

I learned a lot myself while teaching. My vocabulary is much better now. Every time when I read anew text, I would write new words and look for the definitions in the dictionary because I don't want to be an embarrassing situation in front of my students. Before in my English class, our teacher introduces new words ... I learn them and forget later. But here I repeat the words several times in the classroom and there is no way that I will forget them.

This and other narratives confirm that the service learning has a positive impact on participants' English language skill because service learning provided them with authentic language teaching context to sharpen their academic skills. Also, the analysis of observation and reflective narratives demonstrated that students felt confidence and competency in their teaching. This, as the analysis of the reflective narratives, demonstrate, can be due to several factors that SL project provided 1) non threatening environment in sense that there was no head teacher who would grade their teaching as it was during their formal practicum; 2) opportunity to teach what they have developed and rehearsed prior teaching; 3) coteaching with their peers, not a " real" teacher which created the same power and responsibility in teaching. For example, participant $\mathrm{H}$ narrated:

When I was teaching, I was not afraid of being graded by someone. For example, during my school practice last year, I was so nervous because a head teacher and internship advisor were observing teaching. I know whatever grade they give for my teaching will affect my GPA. ... But here [service learning] nobody graded me, and I felt I was a real teacher." Another participant shared his experience this way: Now, I'm not scared to teach anymore. I became more confident to speak and share my ideas in English through discussions in lesson plans with my classmates and teaching English in English.

One of the most important impacts of the SL according to pre-service teachers' narratives was SL provided them with the opportunity to gain handson experience in not only in teaching but also developing their own lesson plans and delivering them which led to becoming more confident and motivated:
During the regular practicum, I taught the lesson that was provided by ahead teacher. I just followed it and never thought that I can develop my own lesson plan. It was cool to teach what you have created yourself and you knew everything about the lesson ... mmm ... I mean how to start and what comes after what. When I taught before, I would just memorize the lesson plan and teach but here, of course, I did some memorization, but I was teaching in a natural way without memorizing. Also, I wanted to teach it as best as I can because I wanted to see the result of my lesson plan because I developed it. The coolest part of teaching was to teach with my groupmate who was the same as me. He knew as much I knew... and we consulted with each other.

These experiences were overtly emphasized in pre-service teachers' narrative which highlights the positive impact of SL on their gaining confidence which ultimately contributed and enhanced their teaching and language skills. It was interesting to see the reciprocal relationship between pre-service teachers' English language proficiency and confidence in teaching. As it has been mentioned before, prior to actual teaching, pre-service teachers rehearsed their teaching in front of their peers which helped them "polish" their teaching in terms of giving instructions, asking questions, explaining new words, and providing oral feedback only in English as opposed to perform these tasks in Kyrgyz or Russian which led to their language proficiency. All these activities helped them to improve their language skills which eventually increased their confidence and efficacy in teaching. As participant reflected:

In our discussions, we decided to use only English which was very difficult to do at first. Sometimes I just wanted to explain in Russian, but I convinced myself to use only English. Therefore, I reviewed new words and instruction before the class. Later, it was easy for me to do these things. I learned a lot of words myself. You know when you know words, you are more confident, and it makes you feel good about yourself.

One of the noteworthy impacts of service learning was service learning students helped them dispel the common myth or misconception that only who has money and power can help which was a popular myth in the post-soviet republics. During interviews, pre-service teachers narrated that before the service-learning project, they thought only wealth and clout could affect change or only having money and power one can help others. For example, in an excerpt taken from an interview, participant B said: 
This project changed my view how you can help society. Before I thought since I don't have money and power, I could not help anyone.

Another student also echoed this sentiment:

At the beginning of the project, I didn't know that we can help them with our knowledge. I think that we proved that we can help people even without having money. I think this is the most important think I learned.

These and other narratives showed how the service learning changed the students' view of helping others. With the transition from a state-run economy to a market-driven one, so too, came a more capitalistic concept that only through tangible capital and authoritative means could students implement change. In Kyrgyzstan including other post-soviet republics, it is generally accepted that only those with power and money can help others.

Without currency and status, students gained an understanding that they could contribute to society through the intangible assets they possessed: knowledge. This narrative is representative for most of participants:

It was really possible to help others, even you have not much money, every time you have an opportunity to help others.

Further, it was indicated by the pre-service teachers that the techniques and methods used during the course helped students develop their reflective, critical and creative thinking, problemsolving and questioning skills. This was because students researched, analyzed and synthesized the knowledge rather than receiving it directly from the teacher. The opportunities provided by this approach enabled preservice teachers to learn by doing and interacting with each other and this offered multiple perspectives, engagement, and responsibility. All these experiences made learning permanent and helped them learn how to learn. Moreover, SL course content understanding promoted professional and personal growth. Both questionnaires and interviews demonstrated that all 22 pre-service teachers had no previous servicelearning experience. They also said they did not understand the concept of service learning. As we have already noted, student volunteerism was confused with the concept of obshestvenaya rabota. Despite attempts to explain the concept of service learning during initial meetings, most students started.

\section{Conclusions}

The failure to incentivize teaching as an occupation in Kyrgyzstan often results from inadequate and impractical policy solutions borrowed from other educational systems [12]. And, by no means, can service learning, alone, stem the tide of teacher attrition. But by participating in the service-learning project, these 22 pre-service teachers were able to learn lesson-planning skills and to have a practicum, both of which they usually would not have had access to until later in their careers, a combination of which inspired them, and most importantly enhanced SL enhances their English language skills which promoted confidence in teaching. Analysis of reflective narratives and questionnaires revealed that service learning, as a powerful pedagogical approach, had multifold positive impacts on EFL pre-service teachers. First and utmost impact of SL provided an authentic language teaching context for EFL pre-service teachers to sharpen their teaching skills and reflect on their teaching before they embark on their teaching profession. However, apart from providing an avenue for meaningful teaching experience, service learning helped pre-service teachers improve their English language competency through meaningful teaching as well as enhanced their perceptions of contributing to the local community and raised their awareness of needs in the community.

\section{Limitations and Implications}

Even though the results of the study are consistent with other research findings about the positive impacts of SL in EFL teaching, there were some limitations of the study such as lack of departmental support which may be due two main factors a) perception of SL as non-academic altruistic initiative which may affect continuity and sustainability of SL as an alternative pedagogical strategy in EFL teacher education; b) the novelty of SL in country and in the region generally which led to hesitance on the part of in-service teachers to participate in SL so that they can to lead SL project. The results of the study may have several potential implications in English teacher education programs. Firstly, service learning can be used as an alternative practicum platform in teacher training education to provide pre-service teachers with hands-on experience in teaching prior to embarking on their professional field. Also, since one of the salient impacts of the SL on pre-service teachers was the improvement of their English language proficiency coupled with gaining confidence, SL can be used as an additional avenue to the existing formal practicum to enhance preservice teachers' readiness and confidence in teaching. 


\section{References}

[1] Al Barwani, T., Mekhlafi, A and Neisler. O. (2010)." Addressing the challenges of cross-cultural understanding through service learning in higher education: the Oman experience", Citizenship, Social and Economics Education, 9 (3), pp. 179-192.

[2] Ashburn, E. (2009, February). College makes new connections with a service-learning program. The Chronicle of Higher Education. A 25-26. Retrieved from: http://chronicle.com/article/College-MakesNewConnections/1698/.

[3] Bruinsma, M and Jansen, Ellen P.W.A. (2010). Is the motivation to become a teacher related to pre-service teachers' intentions to remain in the profession? European Journal of Teacher Education, 33(2), pp. 185-200.

[4] Dewey, J. (1938) Experience and education. New York: MacMillan.

[5] Garrard, J. G. (1962). The teaching of foreign languages in the Soviet Union. The Modern Language Journal,46(2), pp. 71-74

[6] Knox, M. (2004). In defense of memorization. Retrieved 5, May 2011 from www.cityjournal.org/html/14_3_defense_memorization.html.

[7] Healey, D. (1995). Something to do on Tuesday. Houston: Athelstan

[8] LaMaster, K. J. (2001). Enhancing pre-service teachers field experiences through the addition of a service-learning component. Journal of Experiential Education, 24, pp. 2733.

[9] Maynes, N., Hatt, B. and Wideman, R. (2013). Service learning as a practicum experience in a pre-service education program. Canadian Journal of Higher Education, 43(1), pp. 80-99.

[10]Merrill, M. C. (2005) The cultural and intercultural contexts of service learning. Knowing and Doing: The Theory and Practice of Service-Learning (Kate Chisholm, ed.) New York: IPSL (177-201).

[11] Rusu, A.S., Bencic, A., and Hodor, T.I., (2014). Service learning programs for Romanian students-an analysis of the international programs and ideas of implementation. Social and Behavioral Sciences, 141, pp. 54-161.

[12] Steiner-Khamsi, G. (2010). The politics and economics of comparison. Comparative Education Review, 54(3), pp. 323-342.

[13] Sun Y.Ch., and Yang, F.Y. (2015). I help; therefore, I learn: service learning on Web 2.0 in an EFL speaking class. Computer Assisted Language Learning, 28 (3), pp. 202-219.

[14] Tuzel, A.B and Aksan, S. (2009). Raising language awareness of pre-service English teachers in an EFL context. European Journal of Teacher Education,32(3), pp.271-287

[15] Warschauer, M. (1996). Computer-assisted language learning: An introduction. In S. Fotos (eds.), Multimedia language teaching (pp. 3-20). Tokyo: Logos International.

[16] Wengraf, T. (2001). Qualitative research interviewing: Biographic narrative and semi-structured methods. London: Sage.

[17] Zein, S. (2016). Pre-service education for primary school English teachers in Indonesia: policy implications. Asia Pacific Journal of Education, 36 (1), pp. 119-134. 